\title{
Inovasi Dilingkungan Di Kementerian Sekretariat Negara RI Dilihat Dari Perspektif Knowledge Management
}

\author{
Herman Supriadi ${ }^{\mathrm{a}, 1, *}$, Martani Huseini ${ }^{\mathrm{b}, 2}$ \\ ${ }^{\mathrm{a}, \mathrm{b}}$ Program Pascasarjana Fakultas Ilmu Administrasi, Universitas Indonesia, Jakarta \\ ${ }^{1}$ herman_civil@yahoo.co.id *; ${ }^{2}$ martani0703@yahoo.com \\ * corresponding author
}

ARTICLE INFO

Keywords

Innovation Development; Knowledge Management; SECI; Influencing Factors

\begin{abstract}
The focus of this research is to describe the development of innovations in the Ministry of State Secretariat (Kemensetneg) from the perspective of Knowledge Management including the factors that influence it. This study uses a post-positivism approach with qualitative data collection methods, which result show that the development of innovations in the Ministry of State Secretariat has been going well, judging from the context of Socializaton, Externalization, Combination, and Internalization (SECI). Factors influencing the development of innovation are the existence of strong and effective leadership, the availability of human resources as a lever of change, organizational culture and policies that support innovation, and the supply and use of Information and Communication Technology (ICT) as a driving factor. However, there are still inhibiting factors, namely the limited budget for the development of innovation itself and the many innovations created in the form of applications that have not been integrated in the framework of the ministry's big data through the use of machine learning
\end{abstract}

\section{PENDAHULUAN}

Upaya reformasi birokrasi di Indonesia sebenarnya sudah dilakukan sejak tahun 1998 dengan lahirnya berbagai peraturan perundang-undangan untuk memperbaiki kinerja birokrasi dalam pelayanan publik. Namun, hingga saat ini birokrasi di Indonesia masih belum bisa disebut sebagai birokrasi yang maksimal dalam menciptakan pelayanan publik. Hal tersebut dapat dilihat dari struktur organisasi yang gemuk dan cenderung tidak efisien, sehingga masih dirasakan sangat lamban, masih sering terjadi suap saat pelayanan izin, serta proses yang berbelit-belit. Untuk mencapai tujuan dari reformasi birokrasi yang sesungguhnya, maka Indonesia seharusnya dapat mengambil pelajaran dari pengalaman negara lain seperti Amerika Serikat yang menekankan pentingnya efisiensi pada unit cost efektifitas pada pelayanan publik melalui manajemen, pelatihan, dan pengukuran kinerja berdasarkan merit system (Haning, 2015), kemudian Cina yang melakukan restrukturisasi organisasi pemerintah pusat dan daerah agar fungsi birokrasi berjalan dengan efektif (UN, 1997), maupun Korea Selatan yang juga telah berhasil meningkatkan kualitas penyelenggaraan pemerintah dengan melaksanakan reformasi administrasi melalui implementasi inovasi pada tata kelola administrasi pemerintahan (Yoo et.al, 2002). Apalagi saat ini dunia tanpa terkecuali Indonesia sedang mengalami distruption, dimana semua sistem yang sudah dianggap mapan akan tertinggal apabila tidak melakukan inovasi dan kecepatan.

Tidak ingin merasa ketinggalan untuk melakukan reformasi birokrasi, pemerintah Indonesia pun mencoba membangun birokrasi yang cerdas dan inovatif namun tetap transparan dan akuntabel, maka melalui pidato kenegaraan dalam peringatan "HUT ke-71 Proklamasi Kemerdekaan RI" yang disampaikan oleh Presiden Jokowi (Joko Widodo) bahwa "Birokrasi perlu dobrakan, kreativitas dan inovasi dalam mewujudkan pelayanan publik yang semakin berkualitas yang merupakan bagian dari revolusi mental karakter bangsa”. Setidaknya ada 3 (tiga) langkah yang telah/akan diambil oleh Presiden Jokowi sebagai bentuk komitmennya atas reformasi birokrasi, diantaranya: 1) deregulasi melalui pemangkasan dan penyederhanaan regulasi-regulasi yang menghambat (investasi), 2) debirokratisasi melalui pemangkasan jabatan eselon IV dan 
jabatan eselon III di struktur birokrasi pemerintahan, serta 3) concern terhadap big data yang merupakan salah satu basis dari revolusi industri 4.0.

Big data sendiri pada prinsipnya sama seperti data yang dikumpulkan dan disimpan, lalu kemudian dianalisis. Big data secara sederhana merupakan data yang memerlukan kapasitas pemprosesan melebihi pemprosesan pada sistem basis data (data base) konvensional. Data base disini dapat berasal dari kumpulan-kumpulan data yang ada di setiap kementerian/ lembaga yang diharapkan dapat menjadi big data yang dapat dijadikan sebagai acuan untuk meningkatkan pelayanan publik. Implikasi yang diharapkan dari reformasi birokrasi yang berbasis data ini adalah adanya inovasi terutama inovasi dalam pelayanan publik yang diharapkan mampu meningkatkan kualitas hidup masyarakat melalui inisiatif atau terobosan dari pemerintah selaku instansi/lembaga publik.

Apabila instansi/lembaga publik di Indonesia ingin melakukan inovasi di sektor publik, maka harus diawali dari masalah pemahaman tentang bagaimana membangun inovasi dari stakeholder yang menjalankan kebijakan mulai dari keterbatasan kepakaran, serta perlu adanya pengintegrasian didalam pengembangan sistem inovasi dan pembangunan jika dilihat masih adanya keterbatasan data dan informasi, sumber daya manusia, serta pengintegrasian kebijakan didalamnya. Sebab sumber daya manusia yang unggul, integrasi pengembangan sistem, integrasi kebijakan dan integrasi data adalah beberapa hal yang mendukung agar inovasi pelayanan publik tepat sasaran, tepat kebutuhan dan benar-benar dapat meningkatkan kualitas kehidupan masyarakat.

Meskipun inovasi-inovasi pelayanan publik di Indonesia saat ini dianggap telah berkembang pesat, namun kualitas yang dihasilkannya masih belum menyentuh pada tujuan akhir yang ingin dicapainya. Hal ini dikarenakan bahwa inovasi yang ada masih dilakukannya secara 1) Parsial, dalam arti belum terkoneksinya secara otomatis antara inovasi yang satu dengan inovasi lainnya, 2) Piecmeal, dimana inovasi masih dirasa kurang memberi dampak besar dan kolektif, serta 3) Stagnan, yang berarti inovasi hanya berjalan di tempat. Melihat kondisi seperti ini, seharusnya sebagai instansi/lembaga publik dalam melakukan inovasi pelayanan publik harus dapat melakukan pengembangan inovasi, seperti dengan melakukan transfer knowledge inovasi pelayanan publik yang merupakan tahapan atau mekanisme pembelajaran tentang praktik inovasi yang telah terbukti dari satu pihak ke pihak lain.

Knowledge Management berperan penting dalam membantu meningkatkan efektivitas instansi pemerintah karena dapat mendorong knowledge yang sudah dimiliki untuk meningkatkan kualitas proses pengambilan keputusan (PermenPANRB Nomor 14 Tahun 2011), serta dapat dimanfaatkan dalam perumusan kebijakan dan benchmarking pelaksanaan reformasi birokrasi yang sedang dilaksanakan. Dengan adanya Knowledge Management, organisasi dapat banyak belajar melaksanakan aktivitas yang semakin baik dan efektif sebuah organisasi. Menurut Collison dan Parcell, Knowledge Management adalah wilayah yang kompleks yang menjangkau batas-batas pembelajaran dan perkembangan, teknologi informasi dan sumber daya manusia. Hal ini pernah dideskripsikan oleh Dian Kartika Putri (2017) dalam tulisan di "Majalah Inovasi Setneg" mengenai "Pengembangan Knowledge Management di Lingkungan Kementerian Sekretariat Negara Sebuah Ulasan Ringkas di Kurun Waktu 5 Tahun Terakhir", dimana pada elemen manusia/budaya, biasanya Pimpinan yang ada di unit kerja akan menyelenggarakan rapat untuk membahas permasalahan yang dihadapi atau yang terkait. Selain itu, Pegawai pun didorong untuk mempresentasikan hasil pelatihan/seminar/sosialisasi yang diikuti sehingga knowledge yang didapat dari hasil tersebut dapat diketahui pula oleh Pegawai lainnya, sedangkan pada elemen proses kerja, telah terdapatnya standar pelayanan yang ditetapkan melalui Permensesneg No 23 Tahun 2011 dan prosedur kerja (SOP) melalui Permensesneg No 15 Tahun 2012 sebagai acuan dalam melakukan pekerjaan, dan pada elemen sistem informasi, telah terdapat beberapa sistem informasi dalam bentuk aplikasi digital yang digunakan untuk mendukung pelaksanaan tugas sehari-hari yang dimanfaatkan dalam berbagi knowledge, seperti SPDE, aplikasi email, aplikasi intranet, aplikasi perpustakaan online, dan aplikasi file sharing.

Bentuk aplikasi-aplikasi digital dari sistem informasi tersebut diatas memang telah ditetapkan sejak lima tahun terakhir oleh Menteri Sekretaris Negara Pratikno sebagai satu pilar utama 
reformasi birokrasi internal di Kemensetneg. Melalui aplikasi digitalisasi, diharapkan dapat memberikan layanan teknis, administrasi, dan analisis yang makin berbasiskan teknologi informasi kepada Presiden dan Wakil Presiden, termasuk sebagai unsur yang paling berpengaruh bagi penumbuhan mentalitas, lingkungan serta budaya kerja yang makin kreatif dan inovatif. Upaya terobosan sistem informasi tersebut, utamanya ditujukan untuk memperkokoh infrastruktur pembinaan kelembagaan serta memobilisasi penguatan kapasitas knowledge institusional guna makin mempercepat peningkatan kualitas kinerja Kemensetneg yang berwawasan keunggulan. Komitmen kuat dan dukungan seluruh elemen didalamnya akan menjadi kolaborasi ampuh untuk mewujudkan Kemensetneg didalam membangun institusi yang smart government dengan menjadi kementerian yang lebih baik, lebih progresif, dengan terus menerus melakukan inovasi-inovasi.

Namun, seiring dengan banyaknya pengembangan inovasi-inovasi yang ada di lingkungan Kemensetneg yang kini jumlahnya telah mencapai 153 buah, maka banyak pula evaluasi yang juga ditemukan. Dimana berdasarkan hasil observasi yang dilakukan oleh Peneliti khususnya pada tahapan pengembangan dan pelaksanaan inovasi, seperti pada tahap pengembangan perlu dilakukan perbaikan tata kelola inovasi, dikarenakan belum adanya peraturan dan SOP yang mengatur dengan jelas terkait dengan strategi pengembangan inovasi, yang mana menyebabkan saling tumpang tindihnya antara tugas dan fungsi unit kerja yang melakukan pengembangan inovasi karena masih bersifat sendiri-sendiri belum tersentralisasi, dan pada tahap pelaksanaan perlu diperjelasnya indikator-indikator yang digunakan seperti standar dan prosedur pelakasanaan inovasi, struktur organisasi maupun perlu adanya pengawasan yang fokus menangani inovasi, pencatatan perbaikan inovasi, dan evaluasi terhadap pelaksanaan inovasi.

Maka dari sekian banyak inovasi yang dikembangkan oleh Kemensetneg, Apakah inovasiinovasi tersebut cukup membuat Aparatur Sipil Negara (ASN) atau Sumber Daya Manusia (SDM) yang ada di dalamnya semakin inovatif? Apakah alur kerja semakin baik? Apakah rantai birokrasi semakin pendek? Apakah organisasi semakin lincah? Apakah banyak masyarakat yang merasakan manfaat dari inovasi-inovasi tersebut? serta dapat menjadi inspirasi yang memungkinkan untuk memunculkan inovasi lainnya ataupun menyempurnakan inovasi yang ada, sehingga efeknya adalah kepada perbaikan pelayanan publik. Sehingga dalam penelitian ini, Peneliti akan memotret bagaimana Kemensetneg didalam melakukan sosialisasi, proses internalisasi di dalam organisasi, tahap eksternalisasi dan kombinasi dalam implementasi inovasi yang ada melalui teori Knowledge Management dari Nonaka-Takeuchi dengan menggunakan model SECI untuk melihat permasalahan yang ada secara komprehensif. Tujuan dari penelitian ini adalah untuk menganalisis pengembangan inovasi-inovasi yang ada di Kemensetneg dari perspektif Knowledge Management serta faktor-faktor yang mempengaruhi pengembangan dari Knowledge Management itu sendiri.

\section{KERANGKA TEORI}

\section{Knowledge Management}

Konsep Knowledge Management awalnya berasal dan berkembang di private sector, yang diaplikasikan dengan tujuan untuk meningkatkan dan memperbaiki pengoperasian perusahaan untuk meningkatkan profit maupun keuntungan kompetitif. Selain itu Knowledge Management juga digunakan sebagai perbaikan 1) komunikasi antara top management dengan para pekerja (front liners), 2) proses kerja, 3) menanamkan budaya berbagai knowledge, dan 4) untuk mempromosikan maupun mengimplementasikan reward system berbasis kinerja. Menurut Laudon (2002) Knowledge Management itu sendiri berfungsi untuk meningkatkan kemampuan suatu organisasi untuk belajar dari lingkungannya serta menggabungkan knowledge tersebut untuk menciptakan, mengumpulkan, memelihara, dan mendiseminasikan knowledge organisasi tersebut.

Dalam praktiknya, salah satu konsep dasar dari Knowledge Management adalah dalam pengelolaan knowledge itu sendiri sehingga muncul gagasan-gagasan baru dalam hal ini yang disebut sebagai inovasi yang bermanfaat bagi suatu organisasi yang bersumber dari individuindividu yang melakukan pekerjaan rutinnya, yang kemudian ada proses berbagi (knowledge sharing) ke individu yang lain. Dengan demikian, melalui penerapan Knowledge Management oleh suatu organisasi diharapkan dapat mengetahui sumber utama aset intangible organisasi tersebut 
untuk mempermudah didalam penentuan knowledge seperti apa yang dibutuhkan serta mempertimbangkan knowledge seperti apa yang berpotensi untuk dikembangkan.

Menurut Fernandez dan Sabherwal (2010) setidaknya terdapat 4 (empat) proses aktivitas Knowledge Management untuk meningkatkan dampak Knowledge Management dalam mencapai tujuan organisasi yakni:

a. Knowledge Discovery, yaitu pengembangan tacit knowledge atau explicit knowledge yang baru dari data dan informasi ataupun sintesis dari knowledge sebelumnya. Proses ini mencakup subproses "Combination" (suatu explicit knowledge disintesis menjadi explicit knowledge yang baru/lebih kompleks) dan "Socialization" (sintesis tacit knowledge diantara individu).

b. Knowledge Capture, yaitu proses mendapatkan explicit atau tacit knowledge yang terdapat pada individu, artifak, ataupun entitas organisasi. Proses ini mencakup subproses "Externalization" (menkonversi tacit knowledge ke dalam bentuk explicit knowledge, seperti tulisan, konsep, dan sebagainya), dan "Internalization" (menkonversi explicit knowledge menjadi tacit knowledge).

c. Knowledge Sharing, yaitu proses menkomunikasikan knowledge kepada individu lainnya. Pada proses disini terdapat 3 (tiga) klarifikasi yang penting yakni 1) transfer knowledge dilakukan secara efektif; 2) penerima knowledge dapat mengambil tindakan atas knowledge yang dibagikan; dan 3) knowledge sharing dapat berlangsung diantara individu, kelompok/grup, departemen/ bagian, maupun organisasi yang berbeda. Proses ini mencakup subproses "Socialization" (sintesis tacit knowledge diantara individu) dan "Exchange" (menkomunikasikan atau mentransfer explicit knowledge diantara individu/ kelompok/grup, dan organisasi).

d. Knowledge Application, yaitu utilisasi knowledge agar dapat berkontribusi kepada kinerja organisasi dalam proses pengambilan keputusan maupun pelaksnaan tugasnya. Pada proses ini mencakup subproses "Direction" (menginstruksikan hal-hal terkait knowledge yang dimiliki kepada individu lainnya) dan "Routines" (utilisasi knowledge yang terdapat pada prosedur, peraturan, dan norma yang mengatur action).

\section{Tacit Knowledge dan Explicit Knowledge}

Menurut Nonaka dan Takeuchi (1995:59-60) bahwa "Tacit knowledge is personal, context spesific, and therefore formalize and communicate", sementara "Explicit knowledge is knowledge that can be expressed formally using a system of symbols, and can be easily communicated or difussed. Explicit knowledge may be object based or rule (words, numbers, formulas) or in physical objects (equipment, documents and models)". Dimana tacit knowledge tersebut dapat dibedakan menjadi 2 (dua) dimensi, yaitu:

a. Dimensi teknis, hal-hal yang bersifat informal dan sulit untuk dijelaskan secara "know-how" seperti bakat/talent/kebiasaan yang kemudian menjadi skill.

b. Dimensi kognitif, hal-hal yang berkaitan dengan persepsi, skema, model yang kita terima apa adanya --we take them for granted--.

Beberapa perbedaan antara tacit knowledge dan explicit knowledge oleh Nonaka dan Takeuchi (1995:61) yang dapat dilihat pada tabel dibawah ini

Tabel 1. Dua Tipe dari Knowledge

\begin{tabular}{|c|c|}
\hline $\begin{array}{c}\text { Tacit Knowledge } \\
\text { (Subjective) }\end{array}$ & $\begin{array}{c}\text { Explicit Knowledge } \\
\text { (Objective) }\end{array}$ \\
\hline $\begin{array}{c}\text { Knowledge of experience } \\
\text { (body) }\end{array}$ & $\begin{array}{c}\text { Knowledge of Rationality } \\
\text { (mind) }\end{array}$ \\
\hline $\begin{array}{c}\text { Simultaneous Knowledge } \\
\text { (here and now) }\end{array}$ & $\begin{array}{c}\text { Sequential Knowledge } \\
\text { (there and then) }\end{array}$ \\
\hline $\begin{array}{c}\text { Analog Knowledge } \\
\text { (practice) }\end{array}$ & $\begin{array}{c}\text { Digital Knowledge } \\
\text { (theory) }\end{array}$ \\
\hline
\end{tabular}

Sumber: Andreo Wahyudi 2011 Diolah Dari Nonaka dan Takeuchi (1995:61) 


\section{SECI Model}

Dinamika model knowledge creating berangkat dari asumsi dasar bahwa human knowledge diciptakan dan disebarkan melalui interaksi sosial antara tacit knowledge dan explicit knowledge. Interaksi sosial ini disebut konversi knowledge (Nonaka dan Takeuchi, 1995:61). Menurutnya interaksi sosial inilah yang kemudian berpengaruh pada kualitas dan kuantitas kerja, efisiensi dan efektivitas kerja dari sebuah organisasi/lembaga/institusi/ perusahaan. Terdapat 4 (empat) model dari konversi knowledge yang terjadi pada knowledge creating yaitu:

a. Sosialisasi

Sosialisasi adalah sebuah proses sharing pengalaman dan interaksi sosial ini kemudian memberikan tambahan informasi/knowledge pada tacit knowledge yang dimiliki oleh individuindividu tersebut. Sosialisasi dari tacit knowledge dapat terjadi secara langsung dengan tanpa menggunakan kata-kata atau bahasa, tetapi lebih pada observasi, pengamatan, imitasi dan praktek langsung dari apa yang dilihat. Faktor utama dalam tacit knowledge adalah pengalaman, berbagi pengalaman dengan apa yang dimiliki dan interaksi sosial memudahkan transfer informasi antara individu.

b. Eksternalisasi

Sebuah proses artikulasi dari tacit knowledge ke explicit knowledge adalah ekternalisasi. Suatu hal yang fundamental dari proses knowledge creating, dimana tacit knowledge kemudian menjadi explicit knowledge melalui proses penerjemahan ke dalam model, analogi, hipotesis ataupun model. Konversi knowledge melalui proses eksternalisasi ini dapat dilihat pada proses dialog atau refleksi antar individu-individu dalam sebuah organisasi/lembaga/institusi/perusahaan.

c. Kombinasi

Kombinasi adalah sebuah proses dari sistematika konsep ke dalam sistem knowledge. Model dari konversi knowledge ini merupakan kombinasi dari beberapa perbedaan atau keragaman explicit knowledge yang dimiliki masing-masing individu. Interaksi dari pertukaran dan kombinasi knowledge yang dimiliki dan dilakukan melalui media seperti dokumen, pertemuan-pertemuan, kontak melalui telepon atau melalui jaringan komputer yang ada. Rekonfigurasi dari informasi yang ada terjadi melalui penambahan informasi, seleksi informasi atau juga menggabungkan dan mengkategorisasikan explicit knowledge yang diperoleh. Proses interaksi ini akan menghasilkan knowledge yang baru atau inovasi. Pada konteks bisnis, model kombinasi ini ditemui umumnya ketika Manajer pada level menengah mengartikan operasionalisasi konsep dari visi perusahaan, konsep bisnis atau konsep produk.

d. Internalisasi

Internaliasi adalah sebuah proses dimana konsep explicit knowledge kemudian menjadi tacit knowledge. Proses ini seringkali disebut dengan learning by doing. Ketika pengalaman yang diperoleh melalui proses sosialisasi, eksternalisasi dan kombinasi yang menginternal ke dalam tacit knowledge yang dimiliki oleh seseorang, hal ini kemudian menjadi knowledge yang berharga yang dimiliki seseorang tersebut. Proses explicit knowledge menjadi tacit knowledge lebih memudahkan bila knowledge tersebut tergambarkan dan mempunyai visualisasi di dalam dokumen, manual atau dalam bentuk tertulis. Aktivitas dokumentasi membantu individu dalam proses internalisasi dari pengalaman yang diperoleh dan sekaligus memperkaya tacit knowledge yang mereka miliki. Di samping itu, aktivitas dokumentasi juga memfasilitasi transfer explicit knowledge ke orang lain. 


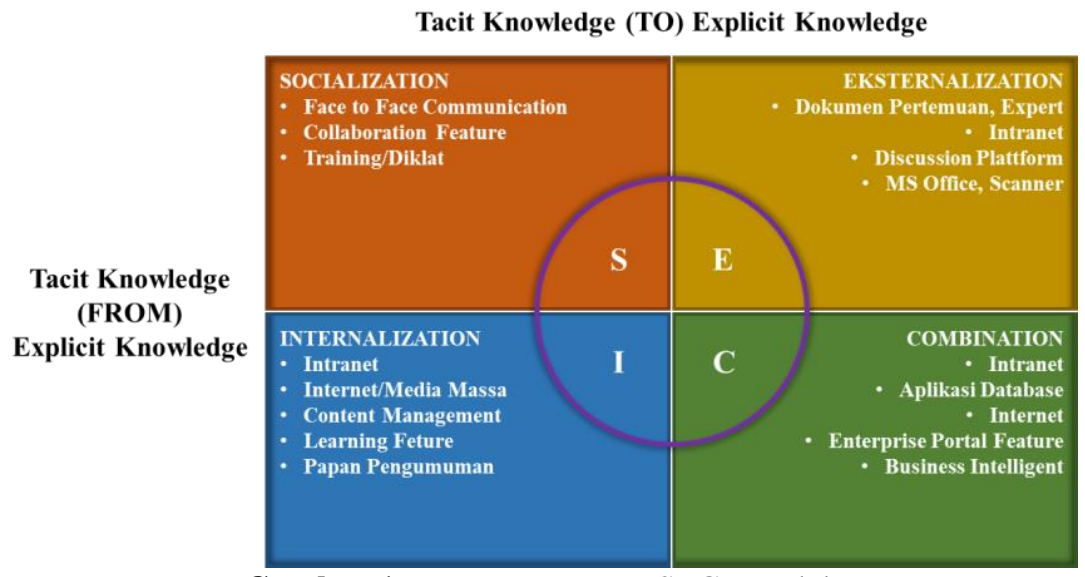

Gambar 1. Pemetaan Proses SECI Model

Sumber: Diolah dari Nonaka Ikujiro and Takeuchi H (1995)

\section{Inovasi}

Dalam buku yang berjudul "Diffusion of Innovation" karya Everett M. Rogers (1983:11), bahwa "An innovation is an ide, practice, or object that is perceived as new by an individual or other unit of adoption", dari definisi tersebut dapat diartikan bahwa inovasi merupakan suatu gagasan/ide yang kemudian diterapkan atau dipraktikan pada suatu kelompok lingkungan tertentu sehingga disadari dan diterima sebagai satu hal baru yang dapat diadopsi oleh lingkungan yang lain.

Selain itu, dapat juga dikatakan bahwa inovasi sebagai suatu proses menciptakan cara-cara, metode, serta ide-ide baru dengan kreativitas yang harus tetap berjalan dalam mengembangkan fungsi pelayanan kebutuhan masyarakat demi keberlangsungan dari organisasi birokrasi. Sehingga banyak Pakar sepakat bahwa inovasi adalah strategi kunci ataupun indikator pokok kemampuan organisasi beradaptasi dengan lingkungannya ataupun untuk bertahan hidup bagi kelangsungan organisasi, karena inovasi mampu membuat adaptasi secara cepat dalam lingkungan yang turbulen, termasuk untuk menyeimbangkan kecepatan yang terjadi di private sector dengan kecepatan perubahan yang terjadi di public sector.

Bila berbicara berdasarkan sektor layanan yang ada yang terjadi di public sector dengan di private sector, maka Ian Miles (2005) membagi karakteristik inovasi dari segi:

a. Pengorganisasian

Di public sector kebijakan baru juga sangat dipengaruhi oleh siklus politik. Public sector mempunyai tugas, tanggung jawab dan kepentingan dalam penegakan dan implementasi kebijakan publik.

b. Struktur Organisasional

Di public sector, organisasi yang ada di dalamnya biasanya bersifat lebih kompleks, cenderung politis dan memiliki kecenderungan konflik satu sama lain. Dalam hal ini inovasi yang ingin diterapkan juga perlu disesuaikan dengan situasi organisasi yang kompleks, termasuk isu kesetaraan sosial dan efisiensi ekonomi.

c. Ukuran Kinerja

Di public sector biasanya mempunyai banyak indikator kinerja yang diterapkan. Ada target yang tertuang dalam rencana kerja jangka pendek, jangka menengah, jangka panjang dan rencana startegis. Oleh karena itu seringkali terjadi kebingungan dalam menentukan kinerja. Akibatnya dampak dari inovasi yang diterapkan sulit untuk diukur.

d. Isu Manajemen

Dalam inovasi di public sector, para Pejabat biasanya bekerja dalam tekanan politik. seperti yang sudah dijelaskan sebelumnya. Inovasi di public sector sangat dipengaruhi oleh siklus politik. Tidak ada independensi yang sesungguhnya, karena kepentingan politik lebih mengemuka. Inovasipun tidak dapat dilakukan tanpa adanya persetujuan politik.

e. Hubungan dengan End-Users 
Di public sector, yang menjadi end-users adalah masyarakat, yang secara tradisional adalah warga negara. Inovasi biasanya tidak didorong oleh faktor end-users, tetapi lebih karena adanya tuntutan atau tekanan politik semata. Di public sector, kadang inovasi kebijakan yang diterapkan sangat bersifat populis. Jadi kadang inovasi yang dilakukan tidak menyelesaikan masalah dalam jangka waktu yang cukup panjang.

f. Supply Chain

Di public sector juga sangat tergantung pada private sector. Dalam hal ini private sector berperan pada pengadaan barang dan jasa. Sementara public sector lebih menentukan standar, private sector menawarkan inovasi.

g. Sumber Daya Manusia

Di public sector, SDM nya atau dalam hal ini para Pegawai bekerja atas dasar idealisme sebagai seorang Aparatur Sipil Negara (ASN). Namun seringkali inovasi dipandang sebagai ancaman. Struktur birokrasi yang cenderung "gemuk" menjadikan inovasi sering kali tidak efektif diterapkan. Inovasi sering dianggap mengganggu stabilitas dan menambah pekerjaan Pegawai di dalamnya, Dalam beberapa hal, inovasi yang ada tetap diadopsi dan diterapkan, penerapan-penerapan inovasi ini khususnya untuk kepentingan perbaikan pelayanan publik.

h. Sumber Knowledge

Di public sector biasanya memanfaatkan sumber knowledge yang banyak, agak kaku, selain kaku di public sector seringkali terhambat oleh prosedur dan ketentuan yang telah dibuat dan ditetapkan sebelumnya. Sehingga yang terjadi adalah dari sumber knowledge satu inovasi ke inovasi lain biasanya tidak sama.

i. Horizon Waktu

Di public sector, pekerjaan dilakukan untuk masa waktu yang lebih panjang (long-term). Karena dilakukan dalam waktu yang panjang ini menyulitkan public sector dalam mengidentifikasi apakah inovasi yang diterapkan keberhasilan atau kegagalan inovasi, karena waktu yang dibutuhkan untuk mencapai tahapan konsekuensi relatif lebih lama dibandingkan dengan private sector.

\section{Inovasi di Sektor Publik}

Inovasi di public sector harus dilihat sebagai salah satu cara yang digunakan oleh lembaga/institusi untuk beradaptasi dengan lingkungan yang semakin dinamis dengan harapan menciptakan pemikiran-pemikiran baru, gagasan baru yang menawarkan program yang inovatif untuk memberikan pelayanan yang memuaskan bagi masyarakat. Hal serupa juga dikemukan oleh Kimberley L. Nelson (2011) bahwa inovasi di public sector tidak hanya sekedar penemuan saja, tetapi juga menjadi dasar lembaga/institusi untuk melakukan perubahan. Perubahan disini salah satunya adalah untuk meningkatkan kinerja. Inovasi ini juga harus menyesuaikan dengan aspek hukum, dukungan dari internal dan eksternal, sumber daya manusia dan iklim kerja, iklim organisasi yang kondusif baik bagi penerapan inovasi. Dalam realisasinya, public sector berinovasi untuk menjaga kepentingan publik. Dengan atribut seperti itu, maka inovasi biasanya menghasilkan metode baru dan menggantikan metode lama dalam mengerjakan atau memproduksi sesuatu. Namun demikian, inovasi juga memperhatikan dimensi geofisik yang menempatkannya baru pada satu tempat, namun bisa jadi merupakan sesuatu yang lama dan terjadi di tempat lain.

\section{Inovasi di Kemensetneg}

Untuk mencapai sasaran utama dari reformasi birokrasi di lingkungan Kemensetneg sebagaimana tertuang didalam Rencana Strategis (Renstra) Kemensetneg yang antara lain: 1) terwujudnya struktur Kemensetneg yang ramping dan responsif terhadap perubahan melalui debirokratisasi, 2) terwujudnya mekanisme, prosedur, hubungan, dan tata kerja serta standarisasi pelayanan efektif, efisien dan transparan melalui deregulasi, 3) terwujudnya sumber daya manusia yang professional, memiliki kompetensi, integritas, dan produktivitas yang tinggi melalui pengembangan mutu SDM, dan 4) meningkatnya mutu layanan kepada Presiden dan Wakil Presiden serta mendukung layanan kepada masyarakat luas melalui transformasi budaya kerja berbasis teknologi komunikasi dan informasi. Maka dengan demikian, sudah menjadi sebuah kewajiban bagi Kemensetneg untuk melakukan inovasi dalam rangka mewujudkan Renstra yang telah disusun dan dievaluasi kemudian hari. 
Sebagai bukti bahwa telah diimplementasikannya pengembangan inovasi-inovasi yang ada didalam pencapaian sasaran Renstra tersebut, maka dapat diketahui sampai dengan saat ini, hampir seluruh pekerjaan di Kemensetneg dibantu dengan penggunaan aplikasi teknologi informasi (TI) yang diciptakan ataupun yang dikembangkan oleh unit-unit kerja di lingkungan Kemensetneg sesuai dengan kebutuhan sekaligus menjadi solusi dalam menyelesaikan pekerjaan. Adapun jenis inovasi yang ada di lingkungan Kemensetneg terdiri atas digital (aplikasi sistem informasi/SI) dan non-digital yang dikembangkan untuk mewujudkan kementerian yang inovatif dan menjadi smart government institution. Berikut beberapa contoh inovasi digital yang ada di Kemensetneg dalam bentuk aplikasi SI/TI, seperti: Setnegpedia, Setneg Office, Sbox, SIAPP (Sistem Informasi Administrasi Pejabat Pemerintah), SMKO (Sistem Manajemen Kinerja Organisasi), APEL (Administrasi Pansel Elektronik), SIPP (Sistem Informasi Penghasilan Pegawai), SIGMEN (Sistem Informasi Gaji Menteri), SPDE (Sistem Persuratan dan Disposisi Elektronik), SIARPUU (Sistem Informasi Analisis Rancangan Peraturan Perundang-Undangan), SIDRENJAD (Sistem Informasi Dukungan Perencanaan dan Penjadwalan Agenda Presiden), SDDKN (Sistem Dukungan Kebijakan Nasional), SIDUJAK-PMPP (Sistem Informasi Deputi Bidang Dukungan Kebijakan Pembangunan Manusia dan Pemerataan Pembangunan), SIGAP (Sistem Informasi Grafis Analisis Penyerapan), SIPA (Sistem Informasi Pelaksanaan Anggaran), SIMSDM (Sistem Informasi Manajemen SDM), SMART LAPAK (Sistem Monitoring Kinerja Penanganan Surat dan Pelaporan Pelaksanaan Kegiatan), SENOPATI (Sistem Online Pengisian Calon Pejabat Pimpinan Tinggi), POSTER (Portal Asesment Terpadu), e-Library, SIMArsip, SIPDumas (Sistem Informasi Penanganan Pengaduan Masyarakat), SIMPEL (Sistem Informasi Perjalanan Luar Negeri), SINDI OKEPOL (Sistem Informasi Dinamika Ormas dan Orpol), LINDU-DIS (Layanan Informasi Terpadu-Drive Thru Information Service), e-PPID: CLICK (Cukup Isi, Klik dan Semua Informasi dalam Genggaman), dll..

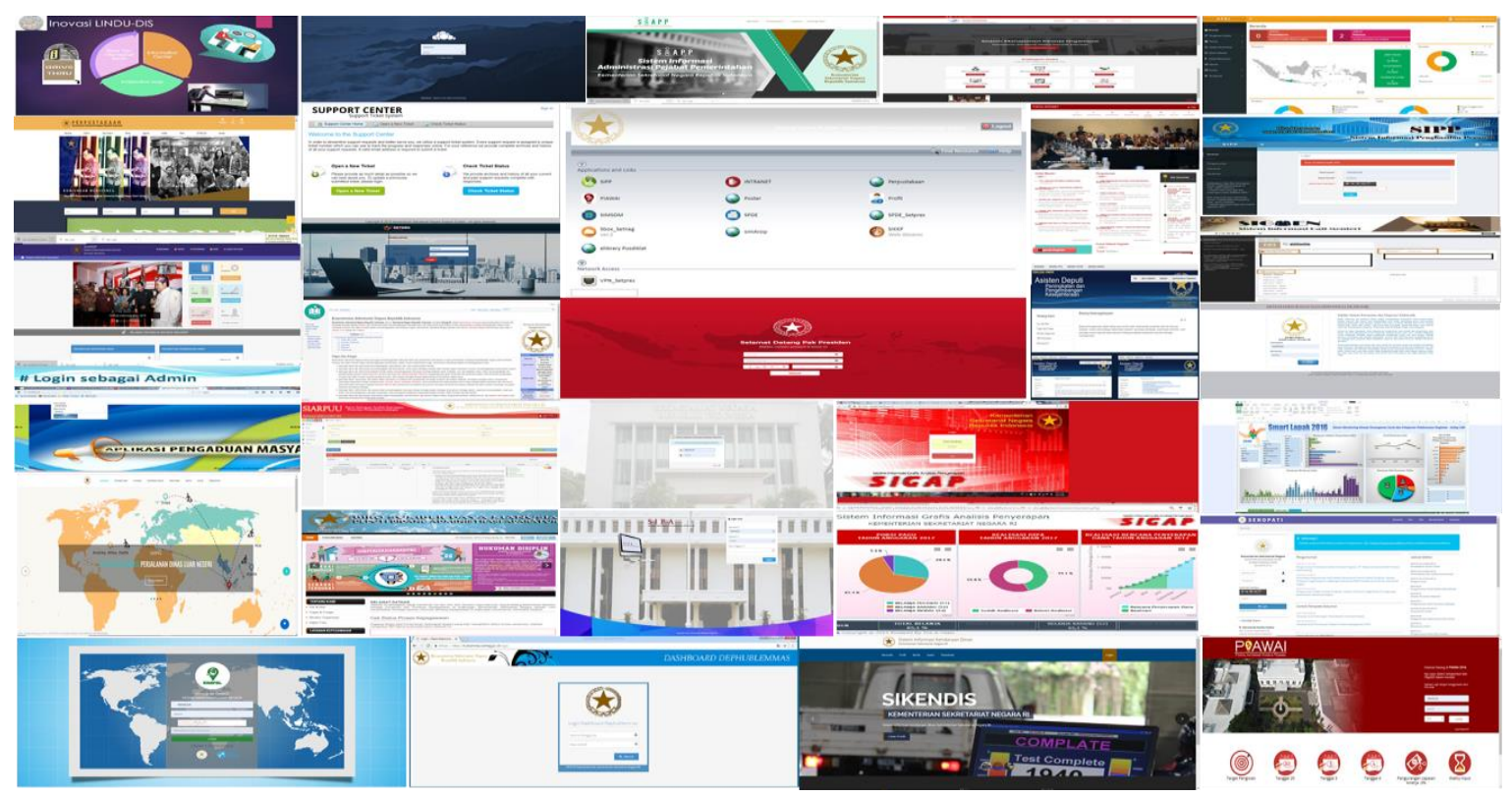

Gambar 2. Aplikasi di Kemensetneg

Sumber: Diolah dari http://intranet.setneg.go.id

\section{METODE PENELITIAN}

Pendekatan yang digunakan dalam penelitian ini adalah post-positivism dengan menggunakan metode pengumpulan data secara kualitatif (Creswell, 2016). Penggunaan pendekatan ini selain karena menggunakan teori sebagai guidance serta adanya variabel yang jelas, juga digunakan agar mencapai sebuah pemahaman yang mendalam (insight) dan menyeluruh (whole) terhadap fenomena yang terjadi. Pendekatan post-positivism dengan menggunakan metode pengumpulan data secara kualitatif melalui konsep teori Nonaka-Takeuchi (1995) menjadi teori utama dan sebagai pisau analisis yang dioperasionalkan dalam menganalisis penelitian ini. Teknik pengumpulan datanya sendiri dilakukan melalui proses wawancara mendalam terhadap 16 (enam 
belas) narasumber. Selain itu, juga dilakukan studi literatur maupun studi terhadap dokumen primer dan sekunder, termasuk penelitian langsung di Kemensetneg yang menjadi locus dalam penelitian ini. Berikut tabel dibawah ini yang menunjukan operasionalisasi konsep dari penelitian.

Tabel 2. Operasionalisasi Konsep

\begin{tabular}{|c|c|c|c|}
\hline Konsep & Variabel & $\begin{array}{l}\text { Dimensi/Sub } \\
\text { Variabel }\end{array}$ & Indikator \\
\hline \multirow{4}{*}{$\begin{array}{l}\text { Knowledge } \\
\text { Managemnt }\end{array}$} & \multirow{4}{*}{$\begin{array}{l}\text { Knowledge } \\
\text { Management } \\
\text { dengan model SECI } \\
\text { dan Faktor yang } \\
\text { berpengaruh } \\
\text { (Nonaka-Takeuchi, } \\
\text { 1995) }\end{array}$} & Socialization & $\begin{array}{l}\text { 1. Penyebaran informasi ke internal dan } \\
\text { eksternal } \\
\text { 2. Media yang digunakan untuk kegiatan } \\
\text { sosialisasi }\end{array}$ \\
\hline & & Externalization & $\begin{array}{l}\text { 1. Forum diskusi instansi/unit kerja } \\
\text { 2. Dokumentasi hasil pertemuan atau notulensi }\end{array}$ \\
\hline & & Combination & $\begin{array}{l}\text { 1. Pembuatan regulasi/kebijakan atau SOP } \\
\text { 2. Pengalokasian anggaran pendukung } \\
\text { 3. Pemetaan SDM pendukung } \\
\text { 4. Penyiapan infrastruktur ITC pendukung }\end{array}$ \\
\hline & & Internalization & $\begin{array}{l}\text { 1. Kepemimpinan di instansi } \\
\text { 2. Budaya kerja yang ada } \\
\text { 3. Intranet/Internet/Media } \\
\text { 4. Fitur pembelajaran }\end{array}$ \\
\hline
\end{tabular}

\section{HASIL TEMUAN DAN PEMBAHASAN}

\section{Penggunaan Konsep Knowledge Management Dalam Pengembangan Inovasi di Kemensetneg}

Salah satu sasaran utama dari reformasi birokrasi yang ingin diwujudkan oleh Kemensetneg dalam rangka pemberian dan peningkatan mutu pelayanan yang lebih baik kepada Presiden dan Wakil Presiden maupun layanan kepada masyarakat luas yakni dengan melakukan transformasi budaya kerja berbasis informasi teknologi dan komunikasi melalui penciptaan dan pengembangan inovasi-inovasi yang bersifat digital (aplikasi sistem informasi) yang ada di Kemensetneg denvan melihat dari perspektif Knowledge Management melalui proses penerapan dasar dalam knowledge creating yang dilakukan dengan model SECI, yaitu Socialization (Sosialisasi), Externalization (Eksternalisasi), Combinaton (Kombinasi), dan Internalization (Internalisasi) (Nonaka-Takeuchi, 1995).

\section{Proses Sosialisasi}

Dalam proses ini terdapat fase awal yaitu terjadinya pengumpulan knowledge yang berasal dari para Pegawai yang ada di lingkungan Kemensetneg melalui penyampaian langsung ataupun sharing mengenai ide atau gagasan baru berupa inovasi-inovasi yang diciptakan ataupun yang dikembangkan baik dalam bentuk aplikasi digital maupun non-digital yang ditujukan sebagai langkah perubahan yang produktif didalam mendukung dan membantu menciptakan tata cara kerja yang lebih baik, efisien, efektif, dan transparan baik dalam bentuk debirokratisasi, deregulasi, dan digitalisasi, yang kemudian direalisasikan dalam bentuk karya atau produk inovasi seperti aplikasi, modul, dan lain sebagainya. Agar karya atau produk inovasi tersebut dapat diimplemantasikan ke seluruh unit kerja yang ada di lingkungan Kemensetneg maupun dapat dimanfaatkan kepada Pengguna lain diluar kementerian, seperti kementerian/lembaga ataupun masyarakat lainnya, maka perlu dilakukan penyebarluasan informasi melalui kegiatan sosialisasi baik secara langsung yakni melalui media mainstream (online) lewat jaringan internet/intranet yang telah disediakan oleh Biro Infotek untuk mendesiminasikan inovasi yang ada seperti Wibesite, Twiteer, Facebook, Whatsapp, Youtube, dsb yang diharapkan rentang waktu yang dibutuhkan untuk mensosialiasikan inovasiinovasi yang ada dapat ter-blasting dengan cepat. Sedangkan untuk sosialisasi yang dilakukan secara tidak langsung (offline) seperti diskusi, face to face, rapat kerja, ajang pemberian penghargaan karya inovasi dan sejenisnya dilakukan tidak hanya oleh bagian Kehumasan namun juga dapat dilakukan oleh unit kerja yang menciptakan atau mengembangkan karya atau produk inovasi. Adapun untuk mengetahui hasil dari kegiatan sosialisasi yang dilakukan apakah telah 
mencapai sasaran yang dituju, maka dapat diketahui melalui alat ukur yang digunakan yakni berupa KPI (Key Performance Indicator) yang dilakukan setiap tahunnya. Sehingga diharapkan dari hasil evaluasi tersebut, Kemensetneg dapat melakukan perbaikan, meningkatkan maupun mempertahankan terhadap inovasi kedepannya.

\section{Proses Eksternalisasi}

Dalam proses eksternalisasi disini terjadi penyimpanan knowledge melalui distribusi knowledge baik yang berasal dari forum diskusi, rapat kerja, maupun bentuk sosialisasi offline lainnya yang diselenggarakan oleh instansi atau unit kerja. Pada proses ini sumber data yang didapatkan untuk menganalisis permasalahan tersebut dapat dikembangkan dan dimanfaatkan untuk meningkatkan knowledge atau kompetensi para Pegawai yang dapat dilakukan melalui unit kerja khusus tidak hanya sekedar Tim Penilai Inovasi yang menangani langsung mengenai inovasi yang dianggap dapat menjembatani bagi para Pegawai dan Pejabat untuk menyalurkan dan mempresentasikan ide dan inovasi, termasuk didalam pemberian feedback dalam rangka perbaikan di kementerian, maupun melalui penyelenggaraan sosialiasasi yang dilakukan secara komprehensif kepada para Pegawai di lingkungan Kemensetneg sebelum inovasi tersebut diimplementasikan di unit kerja-unit kerja lainnya untuk mendapatkan tingkat pemahaman yang merata.

\section{Proses Kombinasi}

Dalam proses kombinasi disini terjadi proses penggabungan dari knowledge yang berbeda yang berasal dari hasil inovasi baik berupa produk kerja, regulasi, SOP, dan bentuk aplikasi lainnya yang ada di laman instansi (wibesite) melalui analisis, pengelompokan, dan penyusunan kembali. Sehingga output yang dicapai nantinya adanya akses informasi atau knowledge yang dibutuhkan oleh Pegawai yang tidak hanya terkait pada bidang kerjanya saja, tetapi juga pada informasi atau knowledge yang berada pada unit kerja lainnya karena telah tersedia keseluruhannya pada laman/portal/wibesite kementerian.

Dalam proses penggabungan tersebut dapat tercapai bila didukung oleh adanya:

a. Pembuatan regulasi/kebijakan/SOP yang mendukung perancangan dari proses inovasi. Mengingat bahwa inovasi merupakan suatu hal yang baru yang diimplementasikan di lingkungan Kemensetneg, maka proses pembuatan regulasi tersebut seperti halnya SOP masih menjadi kendala, karena perlu dilakukannya pembahasan bersama antara biro terkait (Biro Ortala) dengan unit kerjanya, termasuk kesiapan dari inovasi itu sendiri. Sehingga implementasi dari produk-produk inovasi yang ada lebih bersifat melaksanakan perintah Pimpinan ataupun kebutuhan didalam menyelesaikan pekerjaan.

b. Pengalokasian anggaran untuk penciptaan dan pengembangan inovasi sebagaimana disampaikan oleh Mensetneg yang berkomitmen dan memprioritaskan bagi pelaksanaan inovasi di Kemensetneg mulai dari debirokratisasi dan deregulasi, digitalisasi, sampai pada peningkatan kualitas SDM yang dapat berasal dari mata anggaran kegiatan/program pada masing-masing unit kerja maupun sumber alokasi lainnya sehingga dapat membiayai impelementasi inovasi-inovasi tersebut secara maksimal, seperti dengan mencari mitra-mitra yang dapat men-support dari kegiatan tersebut. Usaha tersebut dilakukan agar nantinya tidak menghambat atau memperlambat dari implementasi inovasi yang ke arah "Big Data Analisis". Mengingat belum adanya kebijakan tertulis yang dibuat oleh Kemensetneg dalam rangka mencari mitra-mitra strategis yang akan membantu didalam mewujudkan rencana besar tersebut, sehingga untuk mewujudkannya tidak hanya dapat dilakukan sekaligus dalam satu tahun anggaran. Langkah tersebut tentu telah diinisiasi oleh kementerian pada saat di periode awal, dimana pengalokasian anggaran yang berasal dari APBN pada saat itu berfokus untuk kegiatan menumbuhkan keinginan berinovasi di kalangan para Pegawai seluas-luasnya yang ada di setiap unit kerja serta bagaimana sebuah birokrat menjalankan sebuah tugas dengan lebih ringan, dengan waktu yang lebih singkat, dengan fisik lebih sehat, psikis lebih Bahagia, namun dapat mencapai target yang lebih baik. Karena target berinovasi adalah hasil atau outcome lebih baik dalam menggunakan cost, baik anggaran, waktu, tenaga, maupun pikiran yang lebih sedikit. 
c. Pemetaan ASN unggulan melalui dukungan SDM yang profesional dan kompeten pada bidangnya untuk mencapai suatu organisasi yang berkinerja tinggi. Sehingga dengan melihat ASN sebagai aset negara yang harus dikelola secara professional seperti melakukan penerapan manajemen SDM berbasis merit sistem melalui "open career system" yang merupakan pola manajemen baru yang benar-benar mempertimbangkan kompetensi, capaian kinerja, dan rekam jejak ASN dalam prosesnya sebagai tolok ukur penempatannya. Sementara untuk pemilihan SDM yang memiliki kemampuan dalam melakukan inovasi, maka dilakukan oleh Tim Penilai Inovasi yang dibentuk oleh Mensetneg diluar struktural organisasi dengan melakukan penyaringan, pemilihan, dan penetapan atas karya-karya inovatif terbaik melalui ajang "Anugerah Inovasi Setneg" yang dilaksanakan setiap tahunnya.

d. Penyiapan infrastruktur ITC pendukung melalui rencana pembangunan infrastruktur ITC yang terintegrasi. Adapun bentuk pengembangan inovasi yang akan dilakukan di Kemensetneg dibagi atas 3 (tiga) tingkatan, yaitu 1) untuk inovasi yang memiliki jangkauan luas dan tingkat pengerjaan tinggi, maka penanganan tersebut nantinya akan dilakukan oleh konsultan profesional, 2) untuk inovasi yang memiliki jangkauan tidak luas dan tingkat pengerjaan tidak rumit, maka pengerjaan nantinya akan dilakukan secara kolaboratif dari beberapa tim IT yang ada di Kemensetneg seperti para Penggiat yang tergabung dalam JSIT yang ada di Istana Presiden, Setneg, Setkab, dan KSP, dan 3) untuk inovasi yang memiliki jangkauan tidak terlalu luas dan tingkat pengerjaan sederhana, maka penanganan nantinya akan dilakukan secara mandiri oleh tim IT Setneg.

e. Memanfaatkan kemitraan untuk menciptakan inovasi dengan menjalin kerja sama antara pemerintah dan badan usaha yang didasari atas adanya keterbatasan yang dimiliki oleh masing-masing pihak dalam rangka mencapai tujuan dan sasaran yang ingin dicapai. Seperti untuk inovasi yang memiliki jangkauan luas dan tingkat pengerjaan tinggi, maka perlu menjalin kerjasama dengan mitra yang memiliki kompetensi dan profesional untuk membantu menangani hal tersebut, terutama untuk mewujudkan pengembagan inovasi berbasis Big Data Aanalysis.

f. Pendesentralisasian inovasi dalam pemberian layanan kepada pengguna yang berada di luar Kemensetneg ataupun berbagi inovasi menuju good governance. Dengan begitu, pemanfaatan karya ataupun produk inovasi yang telah diciptakan dan dikembangkan oleh Kemensetneg tidak hanya dapat dirasakan oleh internal, tetapi juga dapat diikuti dan diimplementasikan oleh instansi pemerintah lainnya baik dalam pemberian pelayanan publik yang lebih baik maupun pada proses-proses kerja yang lebih singkat, efisien, efektif, transparan, dan akuntabel.

\section{Proses Internalisasi}

Pada proses internalisasi disini terjadi fase penerapan ataupun pengaplikasian dari knowledge yang sudah didapatkan. Para Pegawai wajib untuk melakukan sharing knowledge, seperti dengan mengakses web untuk menambah knowledge nya, maupun dengan memanfaatkan admin yang ada pada web Kemensetneg dengan melakukan learning by doing melalui tools yang ada, sebagai contoh pada aplikasi SIMSDM, SPDE, PIAWAI, dll. Selain itu, pembelajaran juga dapat diberikan melalui seminar atau pelatihan yang dilakukan oleh Tenaga Ahli/Widyaiswara kepada Pegawai yang lain yang materinya bisa dapat berasal dari data web Kemensetneg baik berupa video demo kerja ataupun narasi, sehingga diharapkan para Pegawai dapat mengetahui bagaimana mempraktikan hal tersebut ketika bekerja. Untuk itu, dalam proses internalisasi disini sangat diperlukan adanya:

a. Kepemimpinan instansi yang kuat untuk mewujudkan visi-misi nya dengan keinginannya untuk mengembangkan digitalisasi sebagai roda penggerak dari debirokratisasi dan deregulasi di lingkungan Kemensetneg, selain mempersiapkan SDM yang unggul untuk menjalankannya. Proses ini dilakukan oleh Pimpinan melalui pemangkasan komunikasi yang biasanya berjenjang. Dengan demikian, Pimpinan akan dapat menanyakan langsung kebutuhan yang diinginkan oleh masing-masing unit yang ada, yang kemudian dimintakan ke mereka untuk mengajukan usulan-usulan inovasi tersebut ke Pimpinan untuk disaring dan dipilih sebagai karya atau produk inovasi terbaik untuk dapat diimplementasikan bagi kepentingan bersama 
didalam membangun institusi pemerintah yang bekerja dengan cerdas (smart government) serta menjadi teladan bagi instansi/lembaga lainnya.

b. Perubahan budaya kerja para Pegawai yang awalnya konvensional menuju kepada digital, yang diyakini mampu mendukung reformasi birokrasi melalui peningkatan kualitas kinerja organisasi maupun pembentukan SDM yang profesional. Untuk itu, dalam merubah budaya kerja Pegawai, maka Pegawai terlebih dahulu harus tahu, paham, bersedia, komitmen dan tindakan.

c. Fitur pembelajaran yang didapatkan melalui proses pembelajaran yang akan ditekankan kepada para Pegawai di Kemensetneg kedepannya, yang tidak hanya sebatas pada kebutuhan yang ada di unit kerjanya saja, akan tetapi lebih kepada tujuan besar kementerian yaitu turut menciptakan Big Data Analisis. Salah satu bentuk pembelajaran yang dilakukan seperti sharing knowledge untuk mendapatkan pengalaman langsung ataupun dengan melakukan visit atau benchmarking ke instansi/badan usaha diluar kementerian yang telah maju seperti Telkom, Telkomsel, Gojek, dsb guna mencari tahu apa yang dapat diimplementasikan didalam Kemensetneg. Sebab dalam era Revolusi Industri 4.0, persaingan hanya dapat dimenangi oleh organisasi yang dapat beradaptasi cepat dengan lingkungannya serta mampu mengadopsi digitaliasasi.

\section{Faktor Pengaruh Pengembangan Knowledge Management}

Berdasarkan analisis pembahasan dalam penelitian ini terkait pengembangan Knowledge Management di Kemensetneg, maka terdapat beberapa faktor yang mempengaruhi, diantaranya:

a. Ada kepemimpinan yang kuat dan efektif

Kepemimpinan memainkan peranan yang sangat penting dalam organisasi serta salah satu faktor yang menentukan berhasil tidaknya suatu organisasi. Sebab peran utama dari kepemimpinan itu sendiri adalah bagaimana mempengaruhi dan mengarahkan orang lain untuk mencapai tujuan yang telah ditetapkan berdasarkan visi yang dibangun oleh suatu organisasi. Dari hasil analisis diatas, diketahui bahwa kepemimpinan di Kemensetneg memiliki keinginan yang kuat untuk mengembangkan inovasi-inovasi terutama dalam hal digitalisasi dalam rangka mewujudkan sasaran utama dari reformasi birokrasi melalui proses penataan ulang, merubah, memperbaiki dan menyempurnakan organisasi didalam meningkatkan kualitas pemberian layanan khususnya kepada Presiden dan Wakil Presiden maupun masyarakat luas melalui transformasi budaya kerja yang berbasis kepada TIK dengan mewujudkan struktur yang ramping dan responsif terhadap perubahan (debirokratisasi), mewujudkan mekanisme, prosedur, hubungan dan tata kerja serta standarisasi, pelayanan efektif, efisien, dan transparan (deregulasi), serta peningkatan kualitas SDM yang profesional, memiliki kompetensi, integritas, dan produktivitas yang tinggi.

b. Budaya organisasi dan kebijakan yang mendukung inovasi

Budaya suatu organisasi mencerminkan norma, nilai dan keyakinan yang ada di organisasi yang menjadi panduan bagi anggota organisasi didalamnya dalam menyelesaikan masalahmasalah yang ada di organisasi. Budaya organisasi juga memungkinkan dapat dilaksanakan Knowledge Management bila suatu organisasi telah memiliki budaya organisasi yang kuat, maka nilai-nilai bersama dipahami secara mendalam, dianut dan diperjuangkan oleh sebagian besar para Pegawai. Budaya organisasi sangat besar pengaruhnya terhadap keberhasilan dan hidup matinya sebuah organisasi. Bagi private sector, mengubah budaya perusahaan (corporate culture) perlu dilakukan untuk dapat selalu beradaptasi dengan lingkungannya yang selalu berubah dengan cepat. Namun tidak bagi public sector yang masih kurang memperhatikan terhadap perubahan lingkungannya, karena masih mengasumsikan public sector sebagai suatu bentuk organisasi yang bersifat stabil, sebab dalam aktivitasnya hanya untuk menjalankan yang bersifat masif dan redundant. Maka apabila bila tugas organisasi dan lingkungannya berubah karena harus mengikuti perkembangan zaman yang lebih maju, diharapkan bentuk dan budaya organisasi yang ada di public sector pun harus berubah, seperti transformasi budaya kerja konvensional kepada digital, yang semula menggunakan kertas 
kerja menjadi paperless melalui pemanfaatan bentuk-bentuk aplikasi berbasis ICT dalam melaksanakan tugas perkantoran.

c. Adanya pelibatan dan partisipasi para stakeholder

Dalam proses pembentukan inovasi di Kemensetneg, maka aktor-aktor yang terlibat dan berpatisipasi aktif tidak hanya berasal dari internal organisasi, juga terdapat aktor-aktor lain yang berasal dari eksternal organisasi. Seperti dengan direkrutnya tenaga ahli atau konsultan atau kemitraan lain yang memiliki kompetensi dan profesional khususnya untuk menangani inovasi yang memiliki jangkauan luas dan pengerjaan yang rumit dalam hal ini "Big data Analysis" yang merupakan pengintergasian semua data base yang ada di setiap unit kerja kementerian ataupun aplikasi-aplikasi yang telah dikembangkan. Pelibatan ini dilakukan tidak hanya untuk meningkatkan kuantitas dan kualitas dari implementasi inovasi saja, tetapi juga untuk meminimalisir terjadinya resistensi terhadap penerapan inovasi melalui partisipasi aktif dari lingkup aktor inovasi yang luas dengan berbagai aset/kemampuan yang dimilikinya baik berupa knowledge, kreativitas, modal, maupun aset fisik lainnya

d. Ketersediaan Sumber Daya Manusia (SDM) dan berkelanjutan

Biro SDM Kemensetneg telah melakukan pemetaan SDM unggulan dengan menyiapkan ASN yang profesional dan kompeten pada bidangnya melalui penerapan manajemen berbasis merit sistem melalui "open career system". Sehingga melalui pengembangan SDM berbasis continuous learning.tersebut, diharapkan nantinya dapat bekerja secara efisien, efektif, dan adaptif terhadap tuntutan perubahan untuk mencapai kinerja organisasi, maupun dapat menjadi active leaner untuk mendukung Kemensetneg sebagai organisasi pembelajar (learning organization), motivator, dan sekaligus menjadi fasilitator bagi seluruh ASN di semua level untuk terus belajar dan mengembangkan diri. Selain ketersediaan ASN yang profesional dan kompetitif, diperlukan juga ASN sebagai lever for change, yakni sebagai pendobrak perubahan dari prinsip-prinsip birokrasi yang selama ini dianggap kaku, yang memandang bahwa tidak diperlukannya inovasi di lingkungan birokrasi pemerintahan yang notabenenya telah memiliki aturan yang jelas, hirarki, spesialisasi, dan lingkungan kerja yang relatif stabil, sehingga ASN telah memiliki kewajiban didalam menjalankan aturan yang yang ditetapkan (rule driven). Jika kemudian inovasi dilaksanakan, hanya dalam intensitas yang kecil dan dilakukan terbatas pada level pimpinan puncak, maka inovasi tersebut lebih bersifat top-down. Sementara inovasi yang terjadi di lingkungan Kemensetneg tidak hanya berasal dari level Pimpinan, tetapi juga pada level Pegawai (bottom-up).

e. Pemanfaatan Teknologi Informasi dan Komunikasi (TIK)

Peran penting TIK dalam Knowledge Management selain untuk memperluas jangkauan dan meningkatkan kecepatan dalam transfer knowledge, juga berperan memfasilitasi komunikasi, menyediakan infrastruktur untuk menyimpan knowledge yang terkodifikasi dan tersampaikan, serta memetakan sebaran bit dan potongan dari tacit knowledge dan explicit knowledge untuk membangun dan mempertahankan ketergantungan antara knowledge. Sehingga melalui kombinasi antara kemajuan knowledge yang didukung oleh perkembangan TIK maka akan mempercepat terjadinya perputaran informasi yang ada. Biro Infotek selaku pengelola inovasi dalam bentuk digital melalui penyediaan infrastruktur TIK harus selalu melakukan penyesuaian dalam menghadapi perubahan yang ada guna menjembatani antara perkembangan dan dinamika informasi yang berlangsung sangat cepat dengan tuntutan pengguna untuk mendapatkan akses informasi dengan cepat, tepat dan akurat.

f. Adanya menyebarkan informasi/sosialisasi dengan cara membangun jaringan horizontal

Banyaknya jumlah inovasi yang telah diciptakan dan dikembangkan oleh Kemensetneg, maka diperlukan sosialisasi yang efektif agar karya atau produk inovasi tersebut dapat dimanfaatkan oleh semua kalangan baik internal ataupun eksternal organisasi. Maka selain bentuk sosisalisasi yang dijalankan melalui media mainstream (online) dan offline, juga dilakukan melalui networked government yang tidak hanya meliputi koordinasi yang efektif antar lembaga pemerintah, namun juga terkait kemungkinan-kemungkinan integrasi baik antara 
organisasi yang profit oriented dan non-profit oriented kedalam sistem produksi, guna mencapai tujuan publik yang efektif dan efisien termasuk didalamnya sebagai strategi penguatan inovasi yang dilakukan. Seperti dalam penerapan aplikasi SIMPEL yang dirancang untuk pelayanan perizinan Perjalanan Dinas Luar Negeri (PDLN) online yang diperuntukkan bagi kementerian/lembaga (melalui focal point) yang akan mengajukan permohonan ijin PDLN kepada Kemensetneg selain pengurusan pada instansi lainnya, seperti di Kemenlu maupun Imigrasi.

\section{PENUTUP}

\section{Simpulan}

Berdasarkan hasil penelitian Inovasi di Kemensetneg Dilihat Dari Perspektif Knowledge Management sebagaimana teori Nonaka-Takeuchi yang melihat dari empat konsep yakni SECI (Sosialisasi, Ekternalisasi, Kombinasi, Internalisasi), maka ada dua konsep yang masih perlu dilakukannya perbaikan untuk pengembangan Knowledge Management di lingkungan Kemensetneg agar lebih baik, yaitu pada konsep Kombinasi dan Eksternalisasi. Sementara itu, dua konsep lainnya telah berjalan sangat baik yakni Sosialisasi dan Internalisasi. Sementara faktorfaktor yang mempengaruhi pengembangan Knowledge Management di Kemensetneg adalah faktor kepemimpinan yang kuat serta kebijakan yang mendukung adanya inovasi, termasuk didalam mengubah budaya organisasi yang lebih efektif, faktor pelibatan dan partisipasi para stakeholder dalam menciptakan, mengembangkan dan mendukung dalam berkreasi dan berinovasi, faktor penyediaan infrastruktur Teknologi Informasi dan Komunikasi (TIK) untuk pemanfaatan pengembangan inovasi berbasis digital, dan faktor menyebarkan informasi/sosialisasi melalui membangun jaringan komunikasi yang baik.

\section{Saran}

Eksistensi peran dari Pemimpin instansi yang sudah kuat dapat diestafetkan ke Pimpinan lainnya, karena Pimpinan instansi pemerintah biasanya bersifat politis. Sehingga jangan sampai bila terjadinya penggantian Pimpinan, maka akan berganti pula kebijakan dan arah pandangannya. Selain itu, agar tidak terjadinya overlapping didalam pelaksanaan tugas dan fungsi pada unit kerja yang melakukan menciptakan dan mengembangkan inovasi maka perlu kiranya dibentuk unit kerja tersendiri secara struktural, bukan hanya sebatas pada pengangkatan Tim Penilai Inovasi berdasarkan SK Menteri yang diangkat pertahunnya saja tapi untuk menjamin kejelasan dan keberlanjutan dari pengembangan inovasi itu sendiri. Kemudian untuk mengembangkan inovasi yang lebih besar "Big Data Analysis" yang merupakan inovasi yang memiliki jangkauan luas dan pengerjaan yang rumit, sehingga memerlukan alokasi anggaran yang besar serta tenaga ahli yang profesional, maka perlu didukung dengan adanya kebijakan Pimpinan didalam mengeluarkan regulasi yang tidak hanya memenuhi prinsip akuntabilitas dan ketentuan yang berlaku saja, akan tetapi kearah pengembangan selanjutnya.

Pada faktor-faktor yang perlu diperbaiki untuk pengembangan Knowledge Management di Kemensetneg kedepannya adalah perlu adanya review dan filter pada karya atau produk inovasi yang bersifat digital (aplikasi) melalui faktor pelibatan dan partisipasi para stakeholder yang tidak hanya sebagai individu atau tim yang menciptakan dan mengembangkan inovasi, tetapi juga pada level Pengguna baik internal maupun eksternal, sehingga dari segi penciptaan dan pengembangannya didapatkan inovasi mudah, aplikabel dan saling terintegrasi.

\section{DAFTAR PUSTAKA}

[1]. Ahmed, Pervaiz K. and Charles D. Shepherd. (2010). Innovation Management. New Jersey: Pearson Education, Inc.

[2]. Asropi. Budaya Inovasi dan Reformasi Birokrasi. Jakarta: Pusat Kajian Manajemen Kebijakan Lembaga Administrasi Negara.

[3]. Awad, Elias M. dan Hassan M. Ghaziri. (2004). Knowledge Management. New Jersey: PearsonPrentice Hall. 
[4]. Azwar, Saifuddin. (2010). Metode Penelitian. Yogyakarta: Pustaka Pelajar.

[5]. Buckman, Robert H. (2004). Building A Knowledge-Driven Organization: Overcome Resistance Free Flow of Idons, Turn Knowledge into New Products and Services, Move to a Knowledge-Based Strategy, New York: Mc Graw Hill.

[6]. Bungin, Burhan. (2011). Penelitian Kualitatif. Jakarta: Kencana Predana Media Group.

[7]. Boomert, B. (2010). Collaborative Innovation in the Public Sector. International Public Management review, Vol. 11, PP. 15-33.

[8]. Creswell, John W. (2015). Penelitian Kualitatif dan Desain Riset: Memilih Diantara Lima Pendekatan. Yogyakarta: Pustaka Pelajar.

[9]. Creswell, John W. (2016). Research Design: Pendekatan Metode Kualitatif, Kuantitatif, dan Campuran (Edisi ke-4). Yogyakarta: Pustaka Pelajar

[10]. Davenport, Thomas, H. and Laurence Prusak. (1998). Working Knowledge: How Organizations Manage What They Know. Boston: Harvard Business School Press.

[11]. Dokumen Human Capital Development Plan (HCDP) Kemensetneg RI. (2019). Bahan Presentasi Biro Sumber Daya Manusia Kemensetneg.

[12]. Drucker, Peter F. (1985). Inovasi dan Kewiraswastaan: Praktek \& Dasar-Dasar. Jakarta: Erlangga.

[13]. Dutta, Soumitra, Bruno Lanvin and Sacha Wunsh-Vincent. (2018). Global Innovation Index 2018: Energizing the World with Innovation $11^{\text {th }}$ Ed. Cornell University, INSEAD, and the World Intellectual Property Organization.

[14]. Effendi, Prof. Dr. Sofian. (2010). Reformasi Tata Kepemerintahan: Menyiapkan Aparatur Negara Unttuk Mendukung Demokratisasi Politik dan Ekonomi Terbuka. Yogyakarta: Gadjah Mada University Press.

[15]. Everett M, Rogers. (2003). Diffusion of Innovation. 5th Edition. New York: Free Press

[16]. Fernandez, I. B. \& Sabherwal, R. (2010). Knowledge Management Systems and Processes. New York: M.E. Sharpe, Inc.

[17]. Filemon A. Uriarte, J. (2008). Introduction to Knowledge Management. Cambridge: Harvard University Press.

[18]. Hermana, Budi. (2005). Model Penerimaan Teknologi Informasi dan Komunikasi: Meta Analysis, http://serpong7.batan.go.id/eII/Rab-RIII-SO-3.pdf.

[19]. Hidayat, L. Misbah. (2007). Reformasi Administrasi: Kajian Komparatif Pemerintahan Tiga Presiden. Jakarta: PT. Gramedia Pustaka Utama.

[20]. Hudayanti, Eka Putri. (2013). Analisis variabel-variabel Knowledge Management di PT. Rekayasa Industri. Jakarta: Universitas Indonesia, Program Pasca Sarjana Ilmu Administrasi Kekhususan Kebijakan Bisnis, Fakultas Ilmu Sosial dan Ilmu Politik.

[21]. Hurley, Robert. F. and Hult G. Thomas. (1998). Inovation, Market Orientation, and Organizational Learning: An Intergration and Empirical Examination. Journal of Marketing, July.

[22]. Laudon, Kneth C. and Jane P. Laudon. (2002). Management Information System: Managing The Digital Firm $7^{\text {th }}$ Ed. New Jersey: Prentice Hall.

[23]. Lawson, B. and Samson D. (2001). Developing Innovation Capability in Organizations: A Dynamic Capability Approach. International Journal of Innovation Management, Vol. 5, No. 3, PP. 377-400.

[24]. Kementerian Sekretariat Negara RI. (2018). Laporan Kinerja Tahun 2017.

[25]. Ihsanudin. 2019. Jokowi: Kita Harus Gerak Cepat Pangkas Regulasi Penghambat Investasi. Jakarta: Kompas.com tanggal 25 September 2019.

[26]. Maharani, Angginita dan Ade Irma Susanty. (2015). Pengaruh Knowledge Sharing Terhadap Inovasi di Direktorat Human Capital Management (HCM) PT. Telekomunikasi Indonesia, Tbk. Jurnal eProceeding of Management: Vol. 2, No. 2 Agustus 2015. Page 1124-1128.

[27]. Majalah Inovasi Setneg. (2017). Suguhan Inovatif Untuk Ulang Tahun Republik Indonesia. Jakarta: Buku Inovasi Setneg 1 Versi II.

[28]. Majalah Inovasi Setneg. (2017). Tradisi Baru Pelantikan Gubernur dan Wakil Gubernur di Istana Kepresidenan Jakarta. Jakarta: Buku Inovasi Setneg 1 Versi II.

[29]. Majalah Inovasi Setneg. (2017). Nusantara Berdendang: Dimana Ada Perubahan, Disitu Ada Peranan Anak Muda. Jakarta: Buku Inovasi Setneg 1 Versi II.

[30]. Majalah Inovasi Setneg. (2018). Mengenal Berbagai Inovasi Pada Aplikasi Perkantoran di Lingkungan Kementerian Sekretariat Negara. Jakarta: Buku Inovasi Setneg 2 Versi II.

[31]. Moore, Mark. H. (1995). Creating Public Value; Strategic Management in Government, Cambridge: Harvard University Press.

[32]. Moore, MH. (2009). Network Government. Washington: Brooking Institution Press.

[33]. Mulgan and Albury. (2003). Innovation in The Public Sector, Prime Minister's Strategy Unit, Cabinet Office: UK, Ver 1.9, October 2003 http://www.strategy.gov.uk/workareas/innovation/index.asp. 
[34]. Nilan, Sari Ratna. (2017). Knowledge Management Melalui Diskusi Tematik Inovasi Pembelajaran di Lingkungan Dephublemas. Jakarta: Majalah Inovasi Setneg Vol. 2 No. 2 Mei-Agustus 2017.

[35]. Nishihara, Ayano Hirose, Masaei Matsunaga, Ikujiro Nonaka and Kiyotaka Yokomichi. (2018). Knowledge Creation in Public Administrations: Innovative Government in Southeast Asia and Japan. Switzerland: Springer Nature.

[36]. Nonaka, Ikujiro and Takeuchi H. (1995). The Knowledge Creating Company: How Japanesse Companies Create the Dynamics in Innovation. Oxford University Press.

[37]. Nugroho, R.H. Bambang B. (2017). Laboratorium Inovasi Disruptif. Jakarta: Majalah Inovasi Setneg 1 Versi II.

[38]. OECD. (2017). Fostering Innovation in The Public Sector. Paris: OECD Publishing.

[39]. Osborne, Stephen P. \& Kerry Brown. (2005). Managing Change and Innovation in Public Service Organizations. New York: Routledge.

[40]. Peraturan Menteri Sekretaris Negara RI No. 6 Tahun 2018 Tentang Rencana Strategis Kemensetneg RI Tahun 2015-2019.

[41]. Putri, Dian Kartika. (2018). Pengembangan Knowledge Management di Lingkungan Kementerian Sekretariat Negara: Sebuah Ulasan Ringkas di Kurun Waktu 5 Tahun Terakhir. Jakarta: Buku Inovasi Setneg 2 Versi II.

[42]. Poole, Marshall Scott and Andrew H. Van de Ven. (2004). Handbook of Organzational Change and Innovation. New York: Oxford University, Inc.

[43]. Porter. Michael E. (1998). From Competitive Advantage to Corporate Strategy. Harvard Business Review. May-June. Pp 117-151.

[44]. Rahayu, Amy S. (2018). Metode Penelitian. Bahan Mata Kuliah S2 FIA UI, 21 Mei 2018.

[45]. Retnoningsih, Endang. (2013). Knowledge Management System (KMS) Dalam Menigkatkan Inovasi LPPM Pergurunan Tinggi. Jural Evolusi Vol 1 No 1, September 2013. hal 76-85.

[46]. Revoldi, RH. (2007). Membangun Keunggulan Inovasi Melalui Inisiatif Manajemen Knowledge Pada Pusat Pendidikan dan Pelatihan Pengawasan Badan Pengawasan Keuangan dan Pembangunan. Depok: Tugas Akhir, Program Pascasarjana Fakultas Psikologi, Universitas Indonesia.

[47]. Riyadi, Aris, Afdini Rihlatul Mahmudah dan Diah Budhi Utami. (2016). Penerapan Knowledge Management: Oral History Penanganan Arsip Bencana Topan Haiyan di Filipina. BACA: Jurnal Dokumentasi dan Informasi. Vol 37 No 2, Desember 2016. hal 99-120.

[48]. Rochim, Abdul. (2019). Ini Pidato Lengkap Presiden Jokowi di Sentul, Bogor.

[49]. Roessner, J. David. 1988. Government Innovation Policy: Design, Implementation, Eavluation. London: The MacMillan Press Ltd.

[50]. Rossignoli, Cecilia, Mauro Gatti and Rocco Agrifoglio. (2016). Organizational Innovation and Change: Managing Information and Technology. Switzerland: Springer International Publishing.

[51]. Rusmiarti, Dewi Ariningrum. (2015). Analisis Difusi Inovasi Budaya Kerja dan Pengembangan Budaya Kerja Pada Organisasi Birokrasi (Proses Difusi Inovasi Budaya Kerja dan Aplikasi Web MRF di BKKBN Pusat). Jakarta: Tesis, Program Pascasarjana Fakultas Ilmu Sosial dan Ilmu Politik, Departemen Ilmu Komunikasi, Universitas Indonesia.

[52]. Sangkala. (2007). Knowledge Management: Suatu Pengantar Bagaimana Organisasi Mengelola Knowledge Sehingga Menjadi Organisasi Yang Unggul. Jakarta: Rajagrafindo Persada.

[53]. Safitri, Dyah. (2011). Berbagi Pengetahuan Untuk Menumbuhkan Inovasi: Studi Kasus di PT. Indosat Tbk. Depok: Tesis, Program Pascasarjana Ilmu Perpustakaan, Fakultas Ilmu Pengatahuan Budaya, Universitas Indonesia.

[54]. Schwab, Klaus. (2018). The Global Competitiveness Report 2018. Switzerland: World Economic Forum (www.weforum.org/gcr).

[55]. Schwab, Klaus. (2019). The Global Competitiveness Report 2019. Switzerland: World Economic Forum (www.weforum.org/gcr).

[56]. Seidler dan Hartmann. (2008). The Use of Tacit Knowledge Within Innovative Companies: Knowledge Management in Innovative Enterprise. Emerald 12, 135.

[57]. Setiarso, Bambang et al. (2009). Penerapan Knowledge Management Pada Organisasi. Graha Ilmu.

[58]. Suminten. (2017). Analisis Knowledge Management Identifikasi Kerusakan Notebook Pada Lestari Computer Menggunakan Model SECI. Jurnal Techo Nusa Mandiri Vol 14 No 2, September 2017. hal 117-124.

[59]. Sutrisno, Prof. DR. H. Edy, M.Si. (2010). Budaya Organisasi. Jakarta: Prenadamedia Grup.

[60]. Terziovski, Mile. (2007). Building Innovation Capability in Organizations: An International Cross-Case Perspective. London: Imperial Collage Press.

[61]. Tidd. (2001). Managing Innovation. Jakarta: Erlangga.

[62]. Valkama, Pekka, Stephen J. Bailey and Ari-Veikko Anttiroiko. (2013). Organizational Innovation in Public Service. England: Palgrave MacMillan. 
[63]. Wibowo. (2011). Budaya Organisasi: Sebuah Keputusan Untuk Meningkatkan Kinerja Jangka Panjang. Jakarta: Rajawali Pers.

[64]. Widayana, Lendy. (2005). Knowledge Management: Meningkatkan Daya Saing Bisning. Malang: Bayumedia Publishing.

[65]. Wijaksana, Angga Utama. (2017). Dari Reformasi Administrasi Konvensional Menuju Inovasi Administrasi Yang Kolaboratif: Sebuah Kerangka Teori. Jakarta: Majalah Inovasi Setneg 1 Versi II.

[66]. Wijaya, Hengki. (2018). Model Proses Inovasi Rogers Dalam Organisasi. Diakses 22 Februari 2019 http://www.researchgate.net/publication/325527346.

[67]. Yang, Kaifeng and Gerald J. Miller. (2008). Handbook of Research Methods in Public Administration. New York: Auerbach Publications, Taylor \& Francis Group, LLC.

[68]. Yoo, Y., Lyytinen, K., and Yang, HD. (2002). The Role of Standard in Innovation and Diffusion of Broadband Mobile Service: The Case of South Korea. Journal of Strategic Information System, Vol. 4:3, PP. 323-353.

[69]. Zakia, Yunida. (2017). Pemanfaatan E-Government Dalam Meningkatkan Kinerja Pelayanan Publik Kementerian Sekretariat Negara Melalui Penerapan Pembelajaran Berkelanjutan di Kalangan Aparatur. Jakarta: Majalah Inovasi Setneg 1 Versi II. 